\title{
The Political Economy of the Image
}

\section{John Roberts}

I want to begin this essay by recalling the reception of the image from another world, a world before capitalism - or certainly on the edge of capitalism and modernity. This is not to fuel us with a comforting bathos, so that we can lose ourselves in what appears to be free of conflict and division, but in order to draw out a point of contrast in a world where images no longer appear to frame the same kinds of needs and desires. In this sense, before we analysis the political economy of the image today, I want to present a moment of partial withdrawal from exposure to our familiar para-technological-image regime.

At the beginning of his great, unfinished and posthumous novel, Henry von Ofterdingen (1802) Novalis produces an extraordinary incantation on the power of the image. Seated around the breakfast table, the eponymous hero of the novel (the medieval poet Henry von Ofterdingen) discusses with his parents, the content of the dream he has recently awoken from. As the narrator recounts: "new images never seen before arose and interfused and became visible beings around him...intoxicated with rapture and yet conscious of every impression, he swam easily with the luminous stream as it flowed out of the basin into the cliff." "This flowing with and through the landscape brings him eventually to the discovery of "tall, pale blue flower", attracting him "with great force." This moment of empathy in the dream becomes the signature encounter in the novel, in which the poet experiences at various points in the narrative moments of intense exposure to the natural world, human beauty, and visual art, in one instance, illustrations in a book owned by cave-dwelling hermit. Thus if Henry von Ofterdingen is an Erziehungsroman, a novel dealing with the education of a person, it is one directed predominantly though the educative power of the image. In this sense the poet's exposure to 'blue flower' in the

\footnotetext{
${ }^{1}$ Novalis, Henry von Ofterdingen, translated by Palmer Hilty, Frederick Ungar Publishing Co, New York, 1964, p17

${ }^{2}$ Novalis, ibid, p17
} 
dream represents a moment of openness to sensuous form. As such, Henry says to his father over the breakfast table, captivated by his recollection, that he has dreamed a dream, "that seems to me to have been more than a dream." 3 Yet, his father scoffs, dismissing Henry's dream and all dreams, as "spindrift." However, his father rejects the dream, not because he believes dreams to be worthless fantasies, but rather, because dreams are not what they once were. That is they have lost their connection to the truths of prophecy. "The times are past when divine apparitions appeared in dreams and we cannot and will not fathom the state of mind of those chosen men the Bible speaks of. The nature of dreams as well as of the world of men must have been different in those days." That is, the prophetic, startling or projective content of dreams have lost their real-world connection to the visions of prophets themselves: "our present-day miracleworking images have never edified me especially." ${ }^{6}$ Henry, though, rejects, his father's admonishments for their crude spirituality. Far from dreams being the repository of a dead or dying prophetic tradition, they are the living manifestation of our sensuous place in the world. "Is not every dream, even the most confused one, a remarkable phenomenon, which apart from any notion of it being sent from God is a significant rent in the mysterious curtain that hangs a thousand fold about our inner life." Henry defends the autonomy of the dream, and as such reminds his father how astonishing dreams actually are, despite their commonality. "If you had a dream for the first time in your life, how astonished you would be, and you certainly would not let anyone talk to you out of the miraculous nature of this happening which has merely become commonplace to us."

This rejection of his father's cynicism encourages his father into recalling an intoxicating dream that he himself had when he was a youth in Rome and was courting Henry's mother. Henry's father enters a farm in the Roman countryside to be greeted by a farmer

\footnotetext{
${ }^{3}$ Novalis, ibid, p18

${ }^{4}$ Novalis, ibid, p18

${ }^{5}$ Novalis, ibid, p18

${ }^{6}$ Novalis, ibid, p18

${ }^{7}$ Novalis, ibid, p19

${ }^{8}$ Novalis, ibid, p19
} 
who is pleased that his guest is a foreigner and a German to boot. The farmer, surrounded by books and antiquities, excitedly show's Henry's father a number of artworks, and "then with fiery imagination he reads some glorious poems." Accepting an invitation to stay the night his father falls asleep and dreams he is back in his hometown of Eisenach. He takes a walk into the countryside, and up through the local mountains, where he discovers an opening in the side of one of the mountains which leads to a stairway. Down the stairway he finds an old man, in a "flowing cloak sat at an iron table" 10 who stares continually at a beautiful girl carved from marble seated in front of him. The old man's beard had grown through the table and covered his feet. The old man then rises and leads Henry's father through various passageways to a green field, which is covered in fountains and flowers. But it is one flower in particular that holds Henry's father's attention - a blue flower. He then sees a vision of Henry's future mother with a child.

Now this complex, recursive set of reflections on the dream-image and dreaming, is a historical fiction. It's hard to imagine such families in the $14^{\text {th }}$ century, seated at the breakfast table, presenting such a sharp distinction between the dream as religious idios (private world) and the dream as a secular realm of autonomous freeplay. The latter would constitute a kind of blasphemy in this period, certainly in its confessional form as presented in the novel. ${ }^{11}$ Indeed, Novalis's anachronistic dialogue between father and son is expressed precisely through the extraordinary modernity of Henry's secular defence of the dream, as if he was paraphrasing Freud's critical reflections on dreams and prophecy. So, in these terms Novalis is projecting his own newly found Romantic attachment to the

\footnotetext{
${ }^{9}$ Novalis, ibid, p21

${ }^{10}$ Novalis, ibid, p21

11 The Catholic Church, in opposition to the everyday Roman-Greco scrutiny of dreams (of their would-be portents and signs), demanded that ordinary Christians reject their dreams, as these were held to be the suspect and impenitent expulsions of the body. Indeed dreams were one of the main channels through which the Devil entered the soul. As such only those who had learned and pious knowledge of how dreams work on human temptation, such as kings, religious leaders and above all monks, could draw conclusions from dreams, by finding morally pertinent messages from God in them. These were 'privileged dreamers', so to speak. Dreams, then, in the early Middle Ages had to be largely repressed, or discussed only in the most clandestine of terms. See ed., Jacques Le Goff, The Medieval World, translated by Lydia G. Cochrane, Parkgate Books, London, 1997, p33
} 
dream as a new source of knowledge into the speech of his imaginary $14^{\text {th }}$ century poet. Like a time traveller Henry speaks from the future to his father, encouraging him to participate in the new knowledge. Moreover, the opposition between the prophetic dream and the dream of sensuous play - which finds its correlation in the poet's empathy with natural form - disrupts any sense that Novalis is encouraging us to take nostalgic solace in the pre-modern image. Through the introduction of anachronistic knowledge the dream-image is given a history and as such becomes a site of conflict; this scene is not, therefore, an invocation of the pre-modern image as undifferentiated, iconic and whole; a sealed off idios. Rather, the complex recursiveness of the passage signifies something quite different: to bring the life of the image into living dialogue. Father and son here, in their passion, disagreement and powers of recall, invoke the image as a living thing. So, the truth of the pre-modern image here lies not in its fetishized religiosity - this is portrayed by Novalis as a dead thing even in the $14^{\text {th }}$ century - but in its capacity for Bildung: the education of the senses and emotions.

One can see therefore, how early Romanticism in this form, becomes a powerful philosophical tributary into the critique of the instrumental and monovalent reception of the image under the rise of capitalism. Novalis' Bildung of the image is one in which the spectator lives with the image as a condition of its truth-value; and as such, Novalis's writing has become pre-figurative for so much of the critical image-work in the $20^{\text {th }}$ century in which living-with as a means of finding out and making meaning, stands against the act of mere interpretation and passing judgement. Novalis's exercise of a slow mimeticism in front of the image is there in Freud's dream-analytics, in Roman Jakobson's formalist specificity as a deformation of generic modes of reception, in Maurice Blanchot's irresolution and 'withdrawal' in front of the image (understanding seeks what escapes it), in Theodor Adorno's critique of hermeneutics, in Jacques Derrida and Paul de Man's respective versions of deconstructive delay, and recently in Jacques Rancière's 'pensive image'. All these models of anti-interpretation are indebted to a Novalian labour of empathy, as a slow education of the senses and intellect. But, of course we don't live in an image-world in which the slow education of the senses and 
intellect is able to make room for such empathy with any degree of conviction. ${ }^{12}$ People don't want slowness, and certainly don't associate it with the education of the senses, of "seeing" as political perception, in the way Viktor Shklovsky and Boris Eichenbaum took for granted in the 1920s. In fact, living with images as an opening up to the world seems strangely jejune, a liability, a direct and provocative affront to the turnover of the technological image and of passing desire and interest. If this is the 'common place' condition of the beholder under the spectacle's transitory distribution of the image, it is also evidence of the continuing crisis of the link between the 'critical image' and the construction of a critical public, as reflected in the double crisis of the (painterly) modernist image and the veridical documentary ideal in the second half of the $20^{\text {th }}$ century.

What was axiomatic to the success of both these traditions was the linking of production of the image to strong communities of reception. Even though these two traditions were in some sense opposed ideologically and technically, nevertheless, they were united by a shared insistence that the life of the image was a critical and public concern; image and critical public were interdependent. This is because for these publics (professional and non-professional alike) such practices represented a hard-won cultural and political achievement that secured and defined a set of public goods opposed to the prevailing mass cultural and academic settlement. In short, these practices, at their height, educated spectators into a different set of temporal expectations from looking and thinking. For modernism and the early avant-garde: the Hegelian truth of process; for documentary photography: the truth of being there, of placing oneself in the way of the world; and the requirement that the spectator recognize this. These temporal expectations, therefore, socialised the artist/photographer and spectator in a profoundly non-aesthetic way. In asserting the image's transformative place in the world, and as such the partisan idea that certain images-practices might make a difference, these practices offered a point

\footnotetext{
${ }^{12}$ For recent discussions of this condition, see Jonathan Crary, 24/7: Late Capitalism and the Ends of Sleep, Verso, London, 2013, and Ben Noys, Malign Velocities: Accelerationism and Capitalism, Zero Books, Alresford, Hants., 2014
} 
of contrast between what the artist and photographer do and what the expanding imageregime of capitalism does not do or fails to do.

This link between the image and a partisan public of reception begins to break down in the 1960s, as the social base of these publics is subject to political dissolution, with the increasing penetration of the market as the key mediator of cultural value and meaning, and co-extensively the increasing divergence between the left and advanced culture. Now this is not say that these practices and publics were usurped so to speak, as if these traditions were not subject to their own internal problems of renewal, given the change in political and cultural context. But nevertheless, in the light of these new conditions, their influence and efficacy shifted, bringing to the end what Blake Stimson, has called that long "Enlightenment hurrah" in art and photography from the beginning of the $20^{\text {th }}$ century to the $1960 \mathrm{~s} .{ }^{13}$ Indeed, this increasing crisis of legitimacy of the 'image apart', the image of non-relation and dissensus, of critical disclosure, is precisely the cultural and political context out of which Adorno writes Aesthetic Theory in the late 1960s. ${ }^{14}$ As the revolutionary avant-garde retreats even further into historical memory, and the partisan claims of painterly modernism and the legacy of documentary photography appear increasingly attenuated - and as such out of sync with the rise of commercial popular culture - Adorno defends the continuing power of the 'image-apart' to resist the onslaught of mass cultural socialization. And he does this through a particular Hegelian and Novalian move: living with the image has to be the outcome of a special and intimate relationship between the refunctioned artwork and the affective, processual empathy of the spectator. That is, in circumstances where the relationship between the image and partisanship reception has broken down, the image, if it is to create any kind of critical community at all amongst producers and spectators, is compelled to work on two fronts simultaneously: firstly against populism and secondly against aestheticization, as an act of resistance to the production of what we might call a community of the dead or the inattentive (which of course significantly can be both art lovers as much as distracted

\footnotetext{
${ }^{13}$ Blake Stimson, The Pivot of the World: Photography and Its Nation, MIT Press, Cambridge Mass., \& London, 2006

${ }^{14}$ Theodor Adorno, Aesthetic Theory, translated by E.B.Ashton, Routledge \& Kegan Paul, London, 1984
} 
consumers). In these terms the image works to create a new critical public by opening a gap between itself and the ideological consolations of aestheticism and populism. As such, the desire for the ruination or disaffirmation of what has become familiar and tolerable produces a tension between the spectator's experience of the sensuous particulars of the work and the received tradition in which it is grounded, and, as such, a source, potentially, of a new encounter between the labour of reception and the possibility of living with the image as a transformative experience. Hence: the importance of Adorno's own version of mimeticism on this score: the requirement of the spectator to match in animating spirit and cognitive attentiveness, the discontinuous and unfamiliar complexities of the work at hand as a condition of sustaining the life of the image as sensuous concept.

This, of course, is a big demand for the spectator, in which Hegel in some sense outdistances Novalis: living with the image becomes an endless aporetic encounter, as part of an endless refusal to let the image fall - through mere interpretation, received aesthetic judgement and empty approbation - into the realm of commonplace cultural identity and ideological platitudes. This is why the formal implications of art and its links to a critical public here are not just contained with the boundaries of picture making per se, but to a process of formal self-negation. The gap between the image and the received traditions of aestheticized modernism and populism, becomes subject to the necessary dissolution of the image-tradition itself, as the organic boundaries of the art object and image-form (to borrow Peter Bürger's language $)^{15}$ are put under greater strain externally and internally. Thus, although Adorno is writing during the emergence of conceptual art and minimalism (and therefore largely before the huge non-aesthetic impact of post-minimalist and postconceptual modes [as encapsulated in Rosalind Krauss's 'Sculpture in the Expanded Field' (1979)]) the implications of his thinking are clear: the dissolution of the formal boundaries of image production are a condition of the modern's survival as a living tradition. As he says in an extraordinary aside in Aesthetic Theory, contrary to the received understanding of the text: "The widely accepted notion - a bowdlerized theorem

${ }^{15}$ Peter Bürger, Theory of the Avant-Garde, University of Minnesota Press, Minneapolis, 1984 
of aesthetics - [is] that art per se ought to be visual. It ought not. Art belongs squarely to the conceptual realm." ${ }^{16}$ Distance and disaffirmation and abstraction, then, are built into the new as the necessary non-aestheticizing and non-populist encounter with the legacy of the modern and modernism. And, accordingly, this heightened responsibility on the part of the artist and photographer to the instability of the visual as a condition of art's autonomy, becomes the basis for the construction of a new, if highly attenuated, critical public. A critical public can only come into being through identifying spectatorship with what is radically other to the identitary and customary. Indeed, it is only through this process of disaffirmation (of determinate negation) that, in fact, any kind of critical community can be created at all.

The outcome of this, however, is a tendentious narrowing of the earlier collective partisan communities, as these formal negations of the tradition of the modern are incorporated into the tyrannical calendar of the art market and the turn-over of the art-idea as commodity: that is, the struggle to sustain a critical public emerges in conjunction with, and overlaps with, a multiplicity of micro-professional audiences of art, some sharing positions and ideas - but others not - in a competition over the market visibility of artistic difference and novelty. One of the jobs of these middle-class micro-professional audiences, attached to the private gallery, popular art magazine and museum, is to sustain a 'convivial' and 'accessible' link between artists and collectors.

It is not surprising, then, how easily these micro-professional audiences, after realism and modernism, have become identifiable with the collapse of the notion of a classical public or counter-public sphere under the rise of post-Fordism since the 1990s, and the emergence of a 'market confirming' post-democracy. The multiplicity of audiences has now become central to the extensive marketized socialization of art. This is quite different, therefore, from the exchange of the art object and image-form on the market, in which the artist's originality, perspicacity or novelty secured a strong exchangeadvantage for himself or herself as part of a new (and vanguard) critical constituency - a process, which of course, dominated the production of art under Fordism, largely, from

${ }^{16}$ Theodor Adorno, Aesthetic Theory, p461 
1910-1980. Today, however, art contributes its meanings (even its critiques and negations) to a process of socialization through consumption. That is, art, and even counter-image production itself, takes its place within a political economy of culture in which diversified modes of reception create, as Wolfgang Streeck has put it, "hitherto unknown opportunities for individualized expression of social identities," 17 that owe nothing to the older partisan modes of cultural allegiance associated with realism and modernism.

Sociation by consumption... is monological rather than dialogical in nature, voluntary rather than obligatory, individual rather than collective. It is from this perspective that it seems productive to speak of a particular politics of consumption, associated with the affluent societies of today. In mature post-Fordist markets, where alternatives are in almost infinite supply, it is easy to exit from collective identities that have been established by purchase [or critical tradition], without a need for certification by 'significant others'. ${ }^{18}$

Thus, we should be clear: this critique of this new stage of exchange and consumption is not to be confused with a classical critique of art's function under mass culture, so central to Adorno's and Peter Bürger's critical theory. The assimilation of art's diversification into new modes of digital consumption is not synonymous with the mass cultural marginalization of would-be authentic art practices. On the contrary mass culture is the place where diversification is secured and delivered. As Fredric Jameson has said recently: "everything is possible, but only on condition that it embrace ephemerality and consent to exist but for a brief time, as an event rather than as a durable object." ${ }^{19}$ Hence, art's multiplicitous availability now provides a leading role in this process of socialization-by-consumption by providing key transformative points of identification with 'personal development' and 'individualized taste', or a means simply for casual approbation as in Facebook 'likes' or selfies in front of artworks in galleries and

\footnotetext{
${ }^{17}$ Wolfgang Streeck, 'Citizen as Customers: Considerations on the New Politics of Consumption', New Left Review, No 76, July/August, 2012, p33

${ }^{18}$ Wolfgang Streeck, ibid, pp35-36

${ }^{19}$ Fredric Jameson, 'The Aesthetics of Singularity', New Left Review, No 92, March/April, 2015, p123
} 
museums. This is why the proliferation of a multitude of art markets over the last twenty five years is part of this wide process of post-Fordist market socialization, drawing more and more spectators of art into non-public constituencies of reception for the consumption of art.

One of the consequences of this is a familiar overlapping between the rise of these non-public constituencies and the antagonism to, or distance from, on the part of consumers (in politics and public policy), to collective goods or social goods that advance critical solidarity over and above individualised consumer satisfaction. There is a general weakening between political and historical consciousness and sacrifices of individual utility required for a collective politics (and collective cultural politics). As Streeck says:

As the new market mode leaches laterally into the public sphere through the generalization of expectations of cultivated in the consumption of post-Fordist affluence ${ }^{20} \ldots$. [the] modern markets for consumer [and cultural] goods become a general model for the optimal satisfaction of social needs. ${ }^{21}$

Or, to quote Jameson again, under these conditions of plentitude, alienation from a public culture "does not seem to be a particularly painful or stressful prospect." ${ }^{22}$ Indeed, in the world of the 'art-selfie' this would-be plentitude seems all to the good, a strengthening of choice and individuation. Now this does not mean that the formation of these new marketised constituencies for art cannot provide a space for the interpellation of the radical and dissensual agendas of various forms of art. There is no ontological disconnect between these forms of socialization by consumption and processes of radicalisation and negation, just as the expanded market socialization of needs, quite obviously does not dissolve the exigencies of class-consciousness and representation, and the construction of radical constituencies. But, it does mean that forms of political identification under these conditions will tend to be based on individualist consumer decisions, in the same way contemporary participation in politics - for conservatives, liberals and even radicals alike

${ }^{20}$ Wolfgang Streeck, ibid, p43

${ }^{21}$ Wolgang Streeck, ibid, p42

${ }^{22}$ Fredric Jameson, 'The Aesthetics of Singularity', p125 
- has become predominantly issued-based, and as such, predicated on a kind of particularist get-out clause: namely, the future exit on the part of the political agent from any collective pressures brought by the general will, on the grounds that their own individual issue-based commitments do not necessarily have to comply with the agreed aims of the general will.

Consequently, from a broader perspective, it is possible to see this is as part of a general post-Fordist de-coupling of cultural production and meaning from the collective and partisan functions of the symbolic, that historically linked modernism and realism to a programme of emancipatory transformation external to art: that is, the structural tendency within our para-technological cultural regime towards the fluid de-contexualisation of the image as a condition of its particularist legibility - what we might call, under postFordism, the state and market's interdependent strengthening of the non-symbolic. By, non-symbolic, then, I mean something more than simply what once went under the name of 'reification' and the 'spectacle' in the 1960s or postmodern 'depthlessness' in the 1980s: namely, the systematic expulsion of the image from conflicting claims of 'truth' and 'representation', as a condition of the image's free circulation. The image is naturalized as a mere template for subjective projection or a factual datum, thereby, crowding out the discursive functions and conflictual demands of the symbolic ${ }^{23}$ and its partisan constituencies. In many ways the Internet functions precisely along these lines or, rather, these lines of flight from context.

This is why so many artists today working in the wake of the dissolution of the $19^{\text {th }}$ and $20^{\text {th }}$ century image-form of art - and, therefore, whose work operates broadly in the space of 'art beyond art in the expanded field' 24 - have sought to establish, even engineer, an ideal, discursive community for their practice. In relational aesthetics and post-

\footnotetext{
${ }^{23}$ For a discussion of the non-symbolic, see Vilhelm Flusser, Towards a Philosophy of Photography, Reaktion, London, 2000. See also John Roberts, 'Photography after the Photograph: Event, Archive, and the Non-Symbolic', Oxford Art Journal, Vol 32 No 2 2009, pp.281-298

${ }^{24}$ See John Roberts, 'Art Beyond Art in the Expanded Field', in That's the way we do it, Kunsthaus, Bregenz, 201, pp.46-59
} 
relational aesthetics, and across the whole gamut of contemporary participatory and pedagogic practices, the notion of living with, has become attached to a microtopian model of Bildung: that is, to the centrality of participation and dialogic exchange as the determining condition of the authentic temporal life of the artwork. In this sense the spirit of Hegelian/Novalian delay has become a discursive construct outside of the contemplation of aesthetic particulars, or even the internal relations of the image itself. There is no idios to defend here; reception is participation. Indeed, this decoupling of a critical public from the vestiges of an Adornian mimetic reception of the image, moves the notion of the ideal public into the realm of an Hegelian 'imageless truth': truth is first and foremost that which resists iconicity as the ontological condition of defending the communal life of art.

As such post-Fordist modes of market socialization continue to produce their own internal fissures and moments of resistance and non-compliance, foregrounding the crisis of the image in contemporary artistic production. That is, the rise of modes of postvisualisation through the new forms of participation and group practice is an attempt, paradoxically, to protect the image's relationship to art's status as a public good. That is the secondary or subsidiary function of the image in this work (as a representational remnant or token or temporary icon) is a way of deliberately subordinating the experience of the art to its discursive reception. The image-fragment or image-token, functions internally to the processual and temporal reception of the work. This is why we need to remind ourselves that art, like politics, cannot fully become a particularist object of consumption - of the realm of particularist 'likes' - without destroying its social identity; and therefore, art will find ways of protecting its social identity, even at the expense of the destruction of the visual itself, as Adorno intimates. In other words, whatever monopolistic, compressive and manipulative conditions art finds itself in the current period it can never become completely subsumable under these forces, insofar as art is not something that willingly detaches itself from the public goods of collective solidarity. (One might say, then, that, on a global scale, in the very midst of these compressive and monopolistic conditions, the political reconstruction of the international biennial as a site of counter-hegemonic knowledge production since the late 1990s has been one attempt to 
secure a notional critical public for the image). Art's defence of itself as a public good will therefore continually seek to reclaim art's identity as a living thing as a condition of its social legibility. This is why the production of a critical public - or ideal community for art is not a mere option or luxury, for the very lack of art's social and discursive legibility in the current period continually produces the very desire and need for it. In this sense, the formation of a critical public, the non-identitary reception of the artwork, art's dialogic production, and the struggle for art's social legibility are one; each one interpolating the other, as the basis of stopping, averting, resisting, the flow of the work/image back into the entropic conditions of the capitalist image-continuum. Without this interdependence - or coordinated points of discursive delay and dialogue - there is no image culture, simply the marketised flow of image-like-things and artwork-likethings across the porous boundaries of the art institution, mass culture and network culture; and, therefore, little connection to what still remains vital about Novalis and early Romanticism's concept of Bildung: namely, the life of the image as an expression of a life worth living. 
